\title{
The Queensland Working Party
}

\author{
Spencer Routh
}

Speech notes for presentation of $A D B$ Medal, 11 December 2003

I remember very well how much had to be done when the Queensland Working Party was re-formed in 1975; there were lots of late-night meetings, and lots of speed-reading in between. It is sad that neither of our two fine leaders is here now: Denis Murphy, labor politician, historian and biographer, and Paul Wilson, State archivist, both died from cancer.

I have a tiny story about each. Denis was the chairman of the working party. He proposed that we include a political cartoonist in the $A D B$. None of us had heard of this person; discussion was sceptical. 'OK' said Denis, 'Seeing there's not a consensus, we'll have a vote. Those in favour say Aye'. 'Aye', said Denis, I think alone. 'Those against?' 'No', we chorused. 'The Ayes have it: I've learnt a lot from Jack Egerton'. ${ }^{1}$ As we held him in such admiration and affection, we let him get away with it.

I wrote my first $A D B$ entry on the Queensland jockey and horse trainer Walter Blacklock. It was full of the names of horses and horseraces. Jim Gibbney, the Queensland desk editor in Canberra, was a lovely bloke, but he had no interest whatever in horseracing. After editing the entry, Jim sent me a message: 'Spencer, you must get your man out of the stables for at least a couple of sentences'. I was shattered, particularly as I was about to get on a plane to go on long leave overseas. I shoved the whole mess into the hands of Paul Wilson, who was then the secretary of the Queensland Working Party. I will read you the couple of sentences that conclude my article on Blacklock: 'Small, sturdy and jovial, with a sweeping white moustache, he remained always the quintessential horseman. He failed to learn to drive a motor car, purchased in 1923, which he would try to stop by pulling on the steering wheel and shouting "Whoa"'.

It is still the best conclusion to any of my articles, but I wrote not a word. Paul found someone who had known Blacklock 50 years before, interviewed him, and wrote those sentences. It is a good example of the friendly cooperation that helps hold the $A D B$ project together.

I have been lucky that the conveners of the working party since Denis-Ross Johnston and Pat Buckridge - have not been running personal agendas: they have just wanted to get out a good dictionary of biography.

1 Jack Egerton (1918-98) was a trade union organiser and member of the Australian Labor Party. 


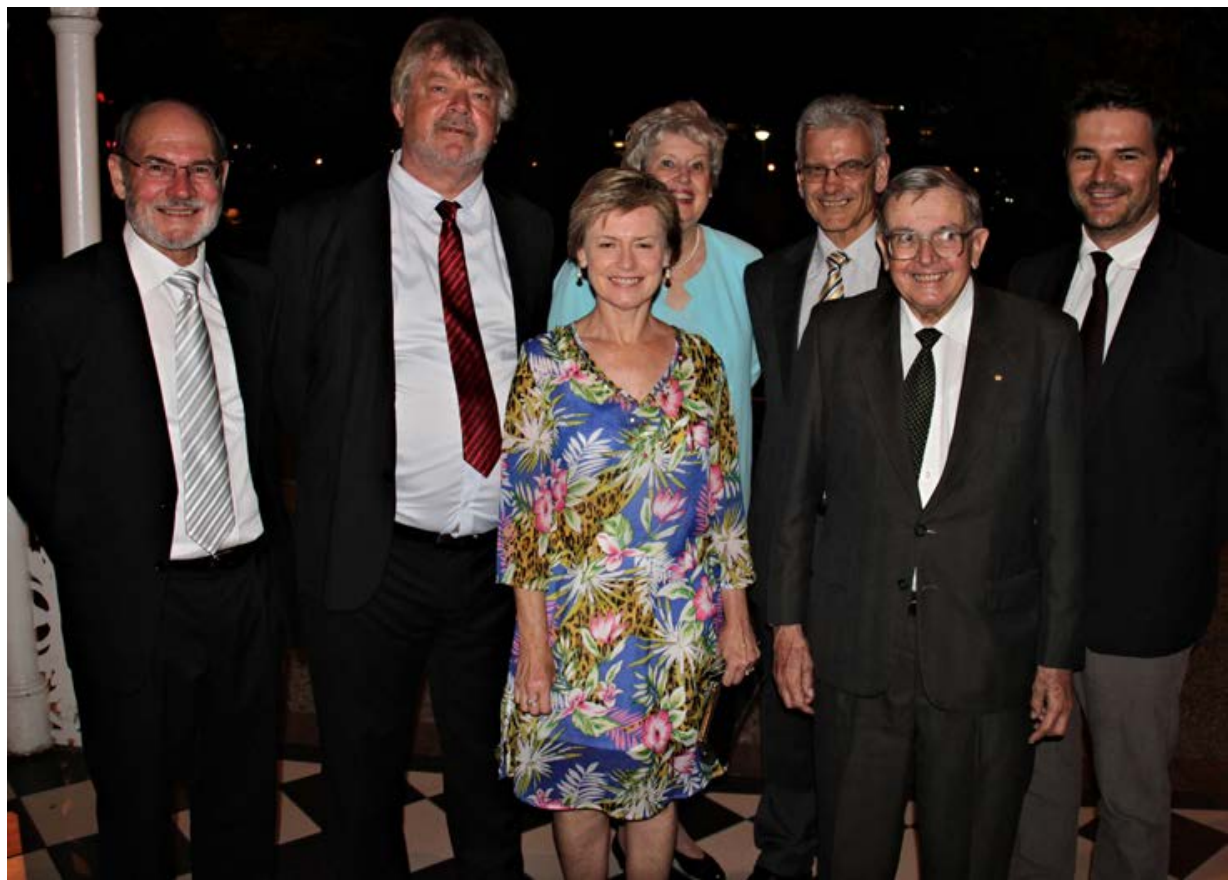

The Queensland Working Party, 2012. Left to right: Darryl Bennet, Brian Stevenson, Libby Connors (front), Jennifer Harrison, Pat Buckridge (chair), Spencer Routh and Geoff Ginn

By courtesy of Cathy Jenkins

I owe debts to many more people. Jennifer Harrison was a paid research assistant for the $A D B$ for many years. She also gave many more hours of unpaid service to the project each year. She was my constant educator and sounding board: 'Jenny, Canberra says the date of this Irish immigrant ship is wrong, and yet to me the source seems so reliable', I would say to her. 'Don't worry, Spencer, you're right. For a while archives had a couple of lists mislabelled. I'll show you how to explain it', she would reply. 'Jenny, this tombstone could be magic for me if only it weren't so weathered. I just can't read it'. 'Don't worry, Spencer, you can trust the published transcription. Those people checked them by X-ray crystallography'. I might have exaggerated that last bit a little, but you get the general theme. She was a great workmate for years.

I will leave anonymous a great crowd of Queensland librarians and archivists who have contributed to the $A D B$ : they could fill this room.

I use mention of librarians to lead on to the three parts of my life with the $A D B$ : helping select subjects; helping select authors; writing articles. Denis Murphy 
encouraged us to range across all fields, but he also gave us a portfolio. Mine was primary production and sport. My present colleagues might say firmly, And how faithful he has been'. But I have taken these fields very broadly.

Many years before the 'smart State' was invented, we were going through the accomplishments of the Department of Primary Industries, checking entomology newsletters for obituaries and the like, to find the scientists who had helped lead Queensland primary production - not always successfully. We included the scientists who introduced the cane toad. At times you look out for representatives - such as the best shearer: Jackie Howe. Often the search is led by events. You look for a couple of people most influential in the switch from British breeds of beef cattle in northern Australia to tropical breeds; a key figure in the transformation of the port of Gladstone; and so on.

We also get suggestions from various sources, with the most fragmentary information attached. For example, for the supplement volume, Abdul Wade, Afghan camel driver, was on a list of potential inclusions. All we had for him were a few sentences from Geoffrey Bolton's book on north Queensland. So you ask yourself, 'But is he the best Afghan camel driver?' So you speed-read books on Afghans in Australia, and books on camels in Australia, and discover that you do, indeed, have the 'Lindsay Fox' of camel transport in Australia-and it is going to be a beaut article.

So you are involved in a mad career of preparation that includes Afghan camel drivers and Aboriginal boxers and State auditors and archbishops and businessmen and so on. A supervisor in the John Oxley Library is entitled to ask, 'What is this surprising bump for a week's stack retrieval figures?' And get the answer, 'Spencer Routh, preparing for an $A D B$ working party meeting'.

Some of the people here tonight are here partly because they have helped meand others - as consultants. It is sad John Kerr isn't here. His books on the sugar industry helped me so much. The specialists we consult about inclusions are always extraordinarily helpful. You go to them at times with some names and notes and they say: 'Doubtful about him. The action came mainly from the minister, or from people lower in the organisation'. Next name: 'Thank goodness you've got her'. Next: 'It's a good one but put this extra theme into your notes for him.' They are part of the friendly network that upholds the $A D B$.

The second theme about my work is helping to recruit authors. A lot of what I have already said applies here also. At times the author is really obvious. But at other times you do bibliographical work, follow some other leads, write a letter with some photocopies of biographical information included, and wait, while saying a little prayer. At times, there are failures. At others times there are great successes. I remember, for example, a phone call in answer to my letter from 
a senior (in age as well as status) scientist. For between five and 10 minutes, I listened to the essence of an authoritative article. When the old scientist drew breath, I could only say, 'If we'd invited anyone else, you'd have sued'.

I have a confession at this point. If I'm not confident that a potential author is as well informed as that scientist, I often send them a little starter kit, containing a few sample articles, obituaries and the like. And I have a deep confession about some authors who have received overwhelmingly useful starter kits. They might have thought 'How generous!'; but I was thinking, 'This subject must be included. I can't for the life of me think of anyone else to write this article; if I don't recruit this person, I'm going to have to write the article myself'. So, some of the generosity has been pretty calculated.

My third work theme: my own $A D B$ entries. For most people here I do not have to describe the long slog of research work, and the contrasting joy of ingenious hypothesis that turns out right. But a couple of comments. I am usually writing up people in fields not dealt with in history honours courses. So I try hard to help the desk editors in Canberra with references for the sources for each statement, and why I have included some sentences. For example, when I say in my text that a Scottish migrant stud breeder imported shorthorn bulls from Scotland, I need to let the desk editor know that in about 1910 there was a great controversy between devotees of a traditional style of beast, and those favouring a new style being developed in Scotland. You could caricature it as basically a contest between cattle that could walk a long way to water, and beef you could actually eat. So I have to educate the editor about the importance of this development so that they will leave it in the entry.

More recently, Chris Cunneen asked me to write up an Illawarra dairy-cattle breeder for the supplement volume. I tactfully asked Chris whether he had a primary industry background - even perhaps a family background in dairying. Chris didn't literally reply that he knew milk had its origin in plastic containers in Woolworths, but I knew the sort of notes I had to write to accompany the article.

My final story about writing for the $A D B$ concerns the buck-jump rider and tent showman Lance Skuthorp. I volunteered for this article because I thought it was going to be easy. There were a couple of editions of a book about him, there was a chapter in another book, and a number of feature articles in popular magazines. The more research I did, though, the more detailed corrections I had to make and big myths dispel. Eventually the article appeared. I waited and watched. Some more of the standard rehashes about Skuthorp appeared. But in 1993 a good coffee-table book about stockmen, including pages on the Skuthorp family, and a detailed page on Lance, were published. It was - I was about to say 'extensively plagiarised' - let us just say, it was written with 'sustained close 
attention' to the $A D B$ article. And no acknowledgment! Was I angry? No. I was delighted. Because in the end we are not in this for the pleasures of cooperation, or the joys of detective work, but to make good introductions to some of the people who have made Australia.

NB: ADB editors have greatly appreciated Spencer's extensively footnoted entries. 
The ADB's Story

\section{Profile}

\section{Spencer Routh (b. 1935)}

Spencer Routh has been a stalwart of the $A D B$ 's Queensland Working Party since he joined it in 1975. He has consistently worked to ensure that representation of Queenslanders - in particular, cattlemen and other primary producers, horseracing identities and sportspeople - is balanced yet comprehensive. This is no accident: Denis Murphy as chairman of the working party (1974-84) allocated 'portfolios' to individual members, a system that his successors have continued; Routh, assigned these particular occupations, has been doing justice to them ever since. Routh's knowledge of his subjects is legendary. Over the years many Queensland authors have received copious bibliographies, elusive references and treasured snippets in the mail; Routh calls them 'starter kits'.

A graduate of the University of Queensland (BA Hons, 1958), Routh was appointed the university library's first reference librarian in 1959, a position he held until his retirement in 1997. He played a major role in developing the library's research collections; in 2005, the university conferred on him an honorary DLitt. His wide knowledge of Queensland university students and their academic interests meant that he could quickly identify appropriate authors for $A D B$ entries. His enthusiasm and helpfulness invariably prompted a positive response from his nominees. Awarded an $A D B$ Medal in 2003, Routh resigned from the Queensland Working Party in 2013.

Source: 'Our Man in the Library: Spencer Routh: Library Legend', UQL NewS (22 December 2005), pp. 1-2. 
7. Working Parties: Recollections of the South Australian Working Party

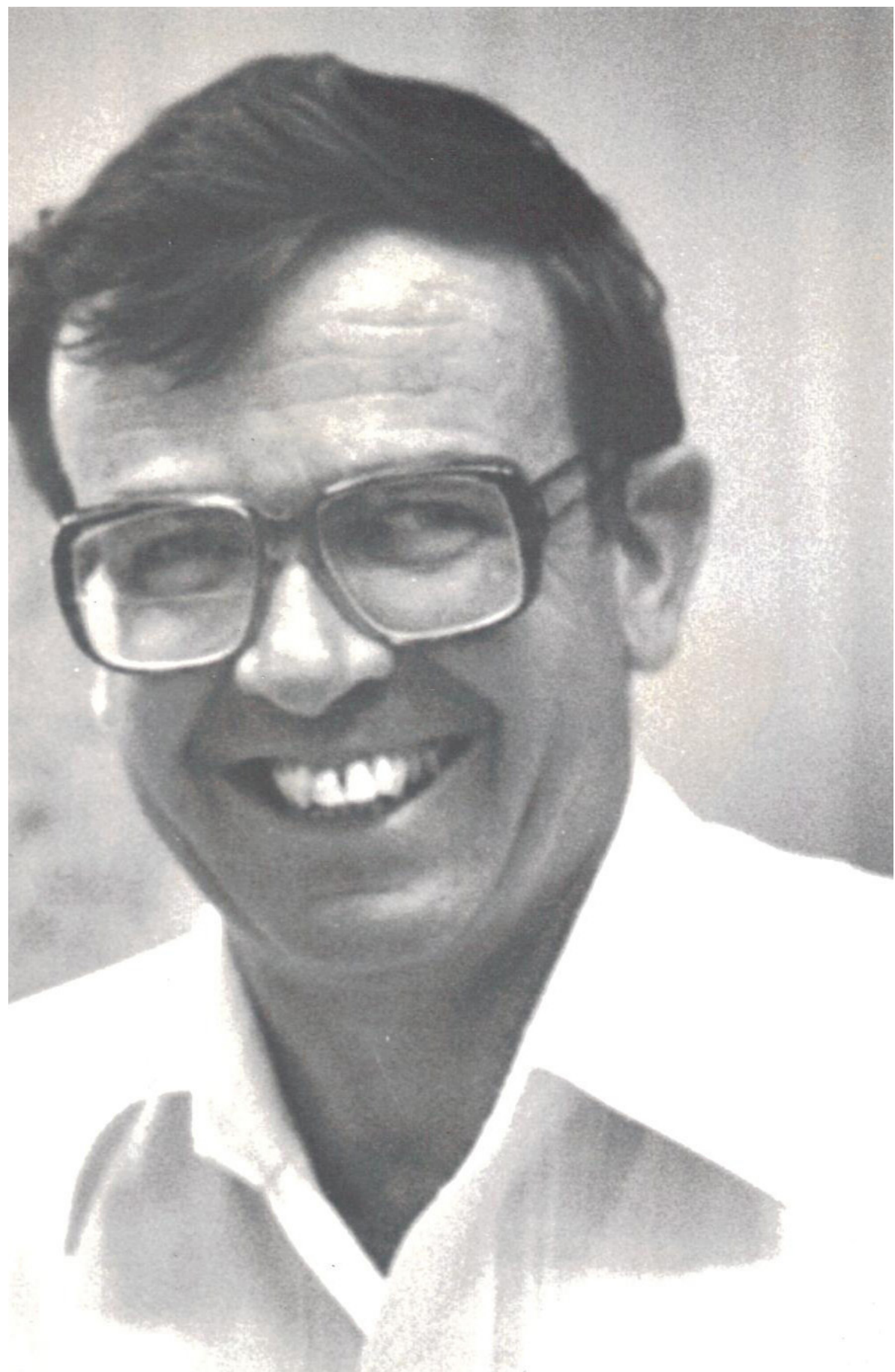

Spencer Routh, 1986

$A D B$ archives 


\section{Profile}

\section{Michael Roe (b. 1931)}

After gaining a PhD from the ANU in 1960, Michael Roe took up a post in the history department at the University of Tasmania. In 1965 he published Quest for Authority in Eastern Australia 1835-1851. Appointed professor of history in 1975, he was a stalwart of the Tasmanian Historical Research Association and much of his work reflects his interest in Tasmanian history and personalities. Other significant books included Nine Australian Progressives: Vitalism in Bourgeois Social Thought, 1890-1960 (1984) and Australia, Britain and Migration, 1915-1940: A Study of Desperate Hopes (1995).

In 1960, immediately after his arrival in Tasmania, Roe joined the $A D B^{\prime}$ s Tasmanian Working Party. From the outset, he carried the administrative burden. Chairman throughout the preparation of Volumes 11-18 (and the supplement volume), he served as section editor for Volumes 13-18 and as a member of the Editorial Board for Volumes 8-18. He resigned in 2012, for health reasons. Roe has written 33 entries for the $A D B$, on individuals as diverse as doctors, photographers, clergymen, educationists, thinkers, journalists, writers, rebels, Aboriginal leaders, and his beloved eccentrics.

Sources: Interview with Professor Michael Roe, Limina: A Journal of Historical and Cultural Studies 2 (1996) pp. 86-91. David Walker and Michael Bennett (eds.), Intellect and Emotion: Perspectives on Australian History: Essays in Honour of Michael Roe (1998). 
7. Working Parties: Recollections of the South Australian Working Party

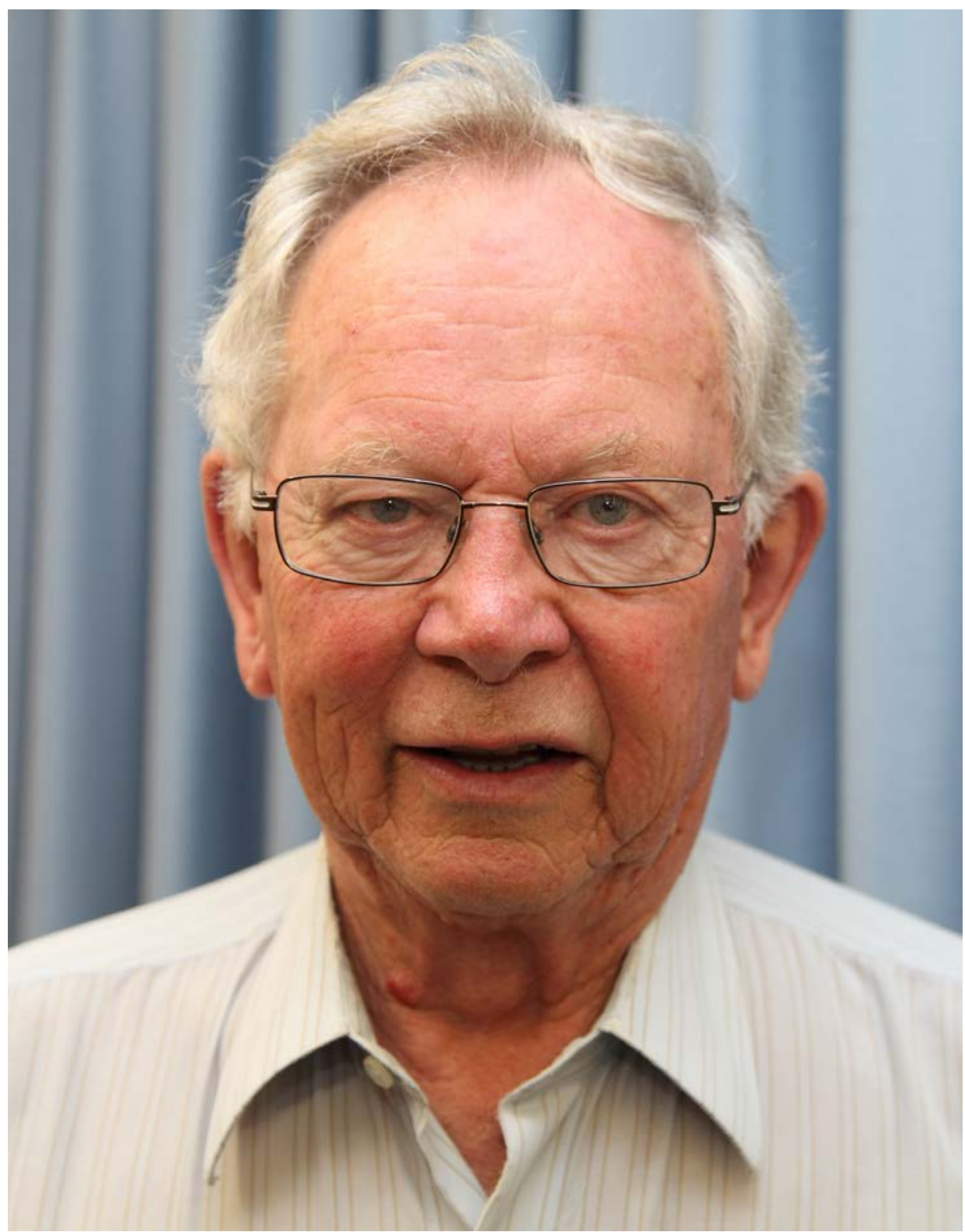

Michael Roe, 2012

Photographer: Brian Wimborne, $A D B$ archives 


\section{Profile}

\section{Wendy Birman (b. 1926)}

A graduate of the University of Western Australia (BA, 1947), Wendy Birman became a qualified librarian. In 1968 she joined the $A D B$ 's WA Working Party, serving as chairman in 1982-96. She gave up library work in 1973 to pursue historical research and, as the $A D B$ 's local research assistant from 1977 to 1996, she built up an unrivalled knowledge of source materials. Interested in the history of exploration in northern Australia, she co-authored, with Geoffrey Bolton, a biography of the explorer Augustus Gregory in 1972 and wrote herself Gregory of Rainworth: A Man in His Time (1979). With Michael White, she wrote The Apprenticeship Training System in Western Australia (1981), a history of the teacher-training system in that State. She has written 57 entries for the $A D B$.

One other important association in Birman's life was the Library Board of Western Australia, of which she was a member for a decade from 1982, and chairman, 1988-92. In that role she did much to promote the development of Western Australia's major archival repositories: the State Records Office of Western Australia and the J. S. Battye Library. She championed the State library's use of emerging electronic technologies and encouraged full engagement with the online world. A prominent member of Perth PEN Centre since its formation in 1984, she has served as State president and delegate to international conferences.

Sources: John Ritchie to Wendy Birman, 22 November 1996 in response to her letter of resignation, 14 November 1996. University of West Australian Graduates Association, 50th Reunion of the Graduates of 1947 (Perth: UWA Graduates Association, 1997). 
7. Working Parties: Recollections of the South Australian Working Party

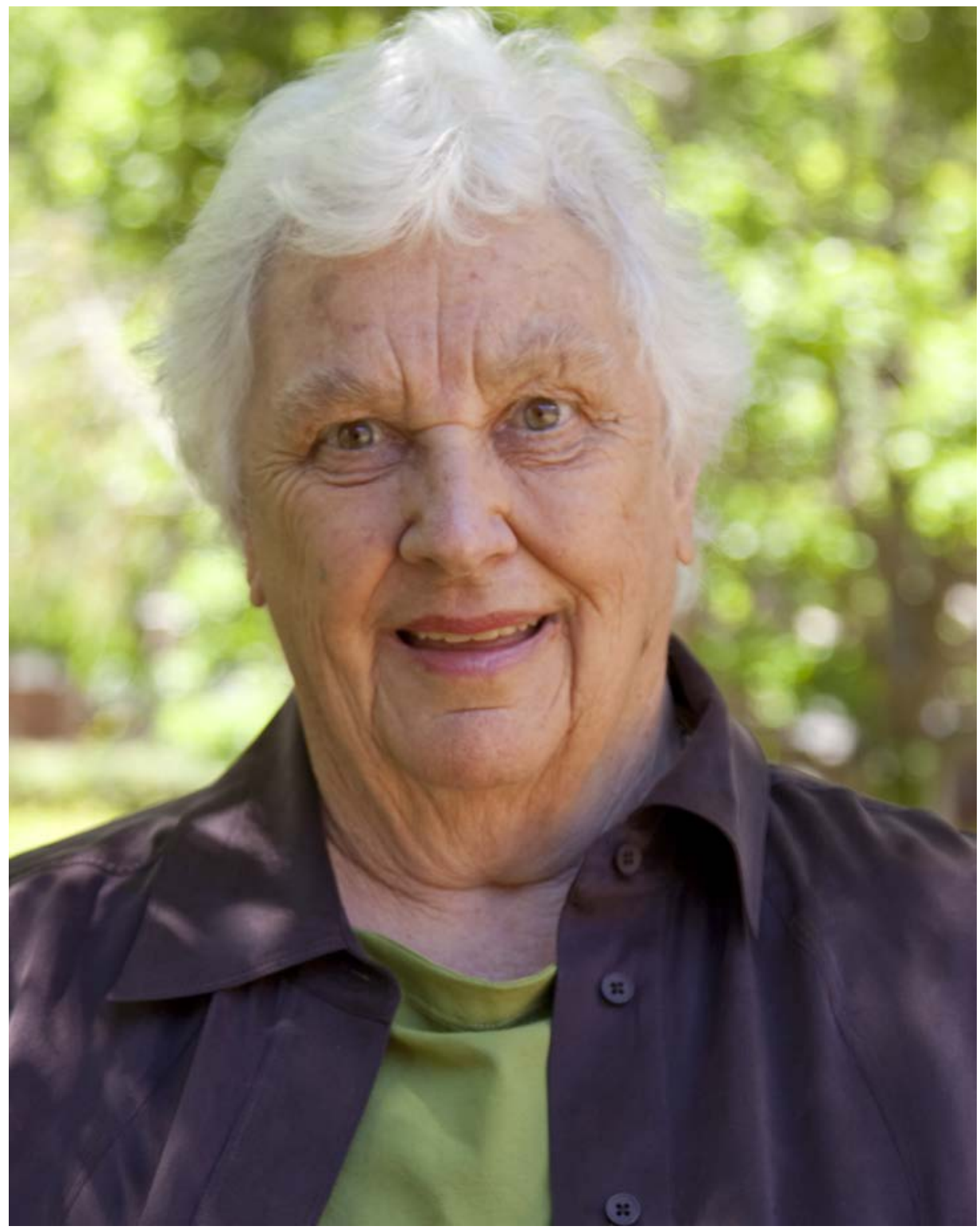

Wendy Birman, 2009

Photographer: Peter Fitzpatrick, $A D B$ archives 
The ADB's Story

\section{Profile}

\section{Cameron Hazlehurst (b. 1941)}

Cameron Hazlehurst's background as a historian and biographer, combined with experience as a senior Commonwealth public servant, were good attributes for a chair of the $A D B$ 's Commonwealth Working Party. Prior to 1989, Donald McDonald (1923-90) was largely responsible for compiling the Commonwealth list; he contributed 27 entries himself. That year, Hazlehurst, then a senior fellow in the Research School of Social Sciences, ANU, brought together a group of Canberrans to form the working party. He served as chairman (and as a member of the Editorial Board) until 1999. The first issue he had to deal with was the title: Gough Whitlam wrote to him in January 1990 arguing that the word 'Commonwealth' should never be used except in 'the Commonwealth of Australia' and that the working party should have been called the 'federal working party' to prevent confusion with the (British) Commonwealth.

As chairman, Hazlehurst continually asked for a larger quota and a higher average word allocation, in order to do justice to Members of Parliament and public servants. He also advocated that all cabinet ministers and heads of government departments should be included in the $A D B$, thereby enabling prosopographical work on cabinet and the public service. He wrote 11 entries on a range of subjects, including Whitlam's father, H. F. (Fred) Whitlam, Gilbert Bogle and Margaret Chandler (more famous in death than in life), and cycling champion Russell Mockridge, plus a film director, deep-sea diver, governor and politician, soldier, aviator and statistician.

Sources: 'Commonwealth Working Party Correspondence', including K. S. Inglis to Cameron Hazlehurst (20 January 1989), and E. G. Whitlam to Cameron Hazlehurst (2 January 1990), box 135, Q31, ADBA, ANUA. 


\section{Working Parties: Recollections of the South Australian Working Party}

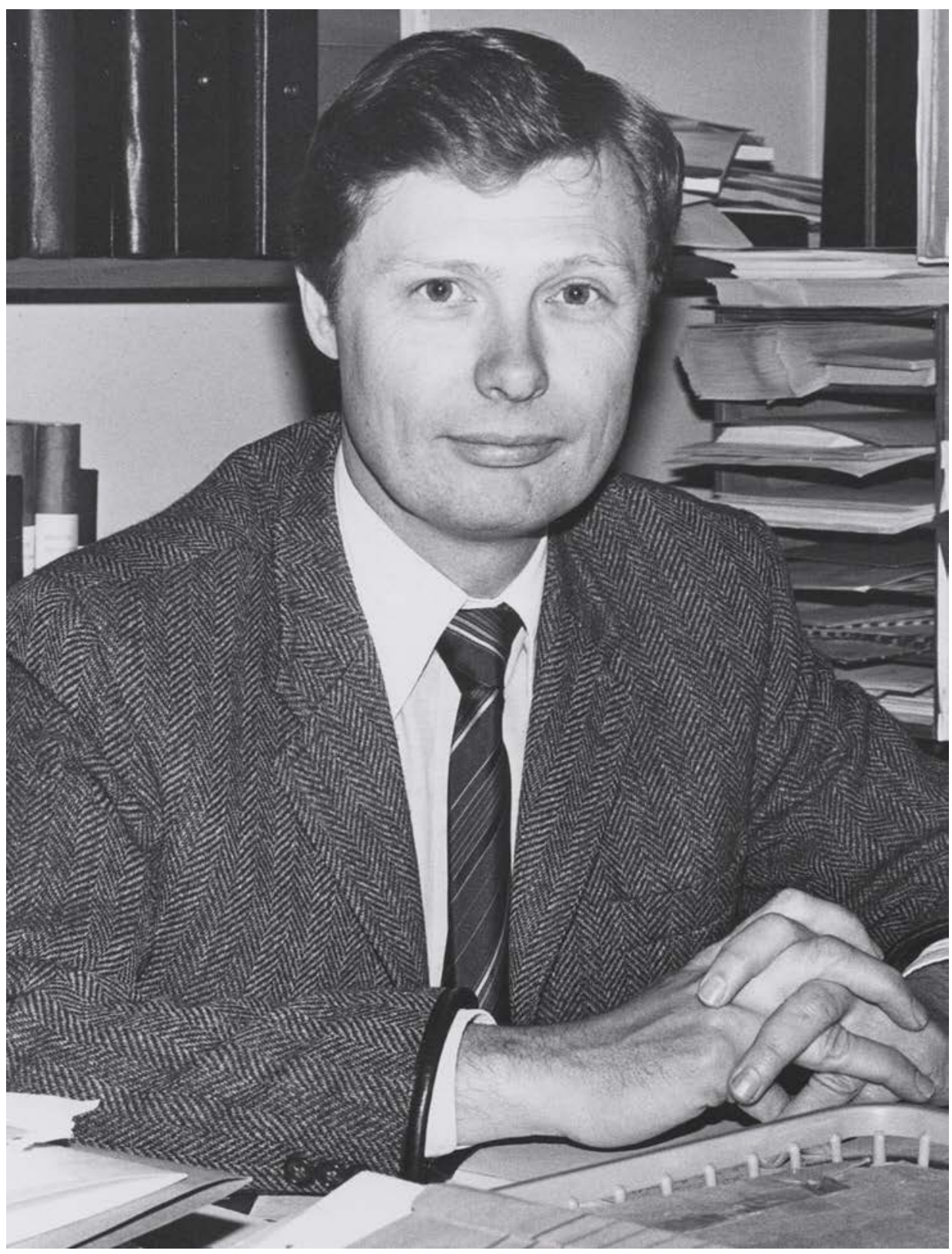

Cameron Hazlehurst in his office in the Coombs Building at the ANU, 1980s

By courtesy of Cameron Hazlehurst 
The ADB's Story

\section{Profile}

\section{Maurice (Bunny) Austin (1916-1985), Alec Hill (1916-2008) and Frank Brown (1906-2000)}

In 1963-65, when he was a research fellow at the $A D B$, the military historian Gavin Long convened an active $A D B$ armed services 'working group'. The Armed Services Working Party, formed in 1974, was responsible for preparing lists for volumes covering the period 1891-1939. Because of the impact of World War I on Australian history, 560 entries, or 14 per cent of the total, had been allocated to the lives of servicemen. On completing the task in 1976, the section editor, Bob O'Neill, wrote that it was a 'major effort' that 'fatigued everyone along the way'. For the list to be realised as entries, an indispensable source were the individual service records, held by the services themselves in repositories such as the Central Army Records Office. The $A D B$ was greatly assisted by a group of retired army officers and historians, including Brigadier Maurice Austin, Captain Alec Hill and Lieutenant Colonel Frank Brown, in gathering this material.

'Bunny' Austin DSO OBE was an army officer (1938-71), who worked from 1971 to 1982 as army historian, researching and publishing works on Australian military history from 1788 to Federation. A consultant to the $A D B$ and a founding member of the Armed Services Working Party, he transcribed-by hand-armed services personal files; after 1982 he had permission to continue accessing the records on behalf of the $A D B$.

Alec Hill AM MBE ED, educated at Sydney Grammar School, University of Sydney (BA, 1938) and Balliol College, Oxford (BA 1948; MA, 1952), taught at Sydney Grammar from 1938 to 1966, interrupted by World War II, in which he saw service in the Middle East and New Guinea. In 1966 he was appointed a lecturer in history at the Royal Military College, Duntroon, where he influenced a new generation of soldiers and military historians, including David Horner (chairman of the working party since 1994), Peter Pederson and Chris Clark, all of whom later wrote for the $A D B$. Associated with the $A D B$ for more than 30 years, Hill was a founding member of the Armed Services Working Party and chairman in 1982-94. He wrote 38 entries, many on prominent generals. His biography of General Sir Harry Chauvel, the commander of the Desert Mounted Corps in World War I, published in 1978, emphasised the role of leadership. 
Frank Brown, a former lieutenant colonel in the Corps of Royal Engineers, was employed by the $A D B$ as a research assistant from 1971 to 2000 . His work, often involving time voluntarily spent far in excess of his reimbursement, was undertaken chiefly at the Australian War Memorial, where he was given special access to service records and war diaries. Brown's careful, well-organised notes were of immense benefit to $A D B$ editors for more than 25 years, until he resigned from the working party at the age of eighty-seven. Bob O'Neill noted in 1974 that his notes were valuable, going 'further than the subjects' military records in many cases'. One opens any armed service subject's file compiled before the late 1990s and sees Brown's handwritten notes adorning the pages.

Source: A. J. Sweeting, 'Long, Gavin Merrick (1901-1968)', Australian Dictionary of Biography, vol. 15 (Melbourne: Melbourne University Press, 2000), pp. 43-4. A. J. Hill, 'Austin, Maurice (Bunny) (1916-1985)', ADB, vol. 17, pp. 119-21. 
The ADB's Story

\section{Profile}

\section{Gordon Briscoe (b. 1938) and Frances Peters- Little (b. 1958)}

Gordon Briscoe and Frances Peters-Little are two Aboriginal historians who have been critical of the $A D B$ not only for failing to identify and include enough Indigenous subjects, but also for not extending its editorial practices to take into account Indigenous conventions of narration and remembrance. Briscoe is descended from the Mardudjara and Pitjantjatjara peoples of Central Australia. From the 1960s he has been active in Aboriginal affairs, helping to establish, in 1971, the Aboriginal legal and medical services in Redfern, Sydney. At ANU (BA Hons, 1986; MA, 1991; PhD, 1996), he was the first Indigenous scholar to be awarded a PhD in history. Peters-Little is the daughter of singers Jimmy Little and Marjorie Rose Peters. A documentary filmmaker, she attended the University of Technology, Sydney (BA, Communications, 1991), and ANU (MPhil, 2002) and is currently a PhD candidate at the University of Sydney, working on a biography of her father.

In an attempt to address the criticisms, an Indigenous Working Party (IWP) was formed in 2004, with Peters-Little as chairwoman and including members Nick Brown, Dawn Casey, Ann Curthoys, Ann McGrath, Margo Neale, Kaye Price, Peter Read and Tim Rowse. Early in 2006 McGrath and Neale resigned and Robin McNamee and Aileen Blackburn were invited to join in their stead. The working party was initially asked to review the lists of Indigenous Australians, already prepared for Volumes 16 and 17 by the State working parties, and to nominate authors. It was also asked to begin collecting names for subjects who died between 1991 and 2000 for inclusion in Volumes 19 and 20. The general editor, Di Langmore, suggested that they decide on 40 names. It soon became obvious that research assistance was needed because everyone was 'overcommitted'. To that end, in 2006, the working party decided to seek a grant from the Australian Institute of Aboriginal and Torres Strait Islander Studies.

More generally, the IWP was meant to advise the general editor on means of ensuring that editorial policy and practice respected the sensitivities of Indigenous families whose deceased kin were included in the $A D B$. In relation to conventions regarding authorship, it took the view that there was no point in laying down general prescriptions about the $A D B^{\prime}$ s editorial policies because Indigenous Australians were not homogeneous in their views on such matters. 
At the end of 2008, Peters-Little, Rowse, Curthoys and Casey resigned for various reasons, mostly to do with relocation. Owing to the loss of key personnel and also as a protest at not having the same functionality as other working parties, the IWP, now chaired by Samantha Faulkner, decided to disband and to recommend to the Editorial Board that an Indigenous advisory board be established with new terms of reference and governance. In 2013 the $A D B$ began to develop a relationship with Yuraki, the History, Politics and Culture node of the National Indigenous Research and Knowledges Network (NIRAKN) of more than 40 members who are all Indigenous academics from across Australia. The node was led by Aboriginal historians Professor John Maynard and Dr Jaky Troy.

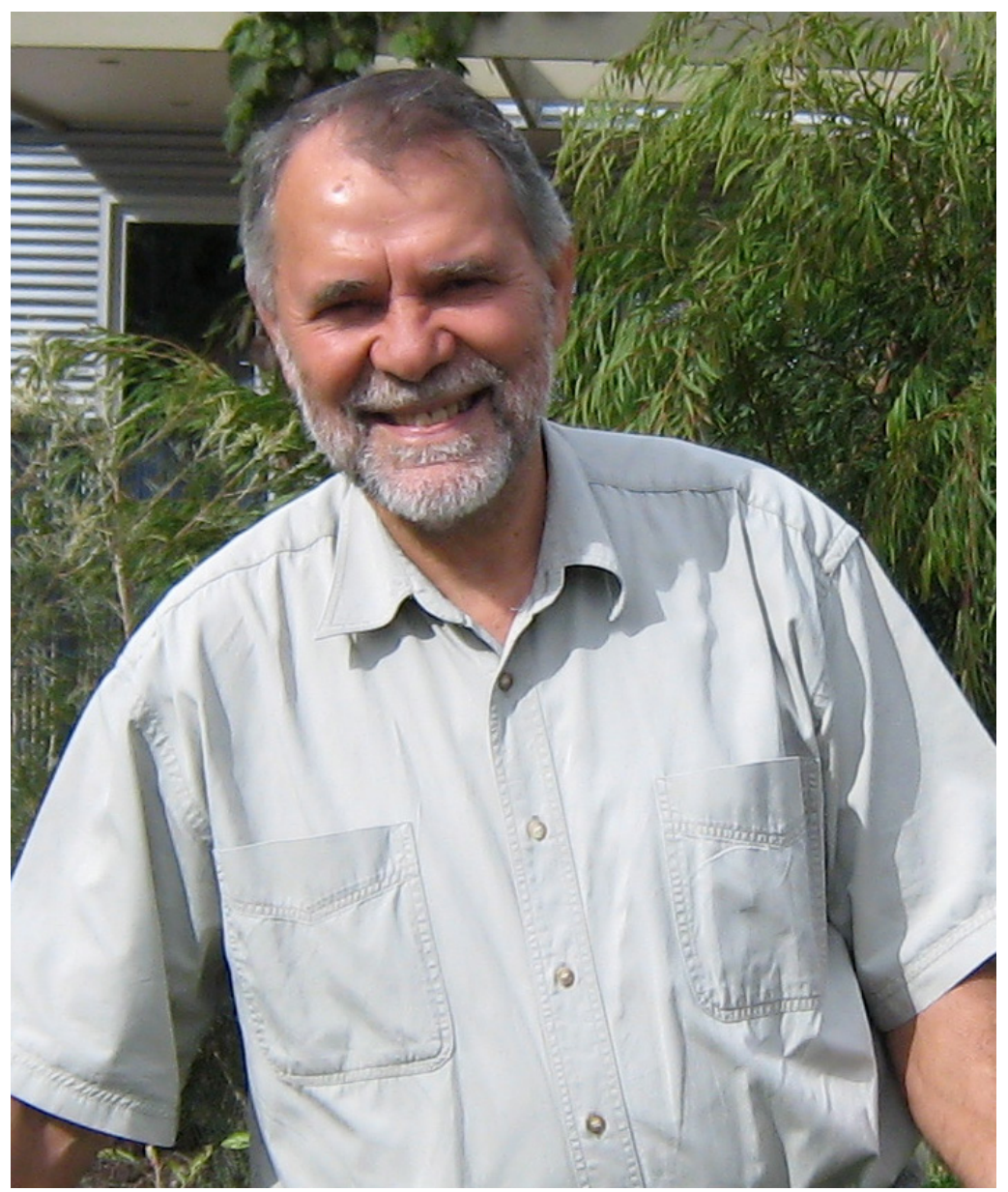

\section{Gordon Briscoe}

By courtesy of Ann McGrath

Source: $A D B$ Indigenous Working Party, $\mathrm{NCB} / A D B$ files. Gordon Briscoe, Racial Folly: A Twentieth-Century Aboriginal Family (Canberra: ANU E Press, 2010). 
The ADB's Story

\section{Profile}

\section{John Poynter (b. 1929)}

A graduate of the University of Melbourne (BA, 1951; PhD, 1961), John Poynter won a Rhodes Scholarship, which took him to Magdalen College, Oxford (MA, 1953). Returning to the University of Melbourne, he was dean of Trinity College before becoming Ernest Scott professor of history (1966-75) and deputy vicechancellor (1975-90). He was a member of the $A D B^{\prime}$ 's National Committee and of the Editorial Board (1974-98) and chairman of the Victorian Working Party and section editor (1978-90). For a dozen years, he read all the Victorian entries, writing erudite comments on the 'blues' that were returned to Canberra. As an $A D B$ author, he has maintained an association that extends back to the 1960s: the first of his 17 entries, on Alfred Felton, was published in Volume 4 in 1972. Many of his subsequent articles, including a 5000-word entry on the Baillieu family and long entries on other significant figures such as the Grimwades, Alexander Leeper, Sir Ronald Munro Ferguson, Dame Mabel Brookes and Sir Charles Lowe, were major contributions. Most are Victorian subjects; all are characterised by solid research and elegant prose. Poynter developed his article on Leeper into a full biography, Doubts and Certainties: A Life of Alexander Leeper (1997).

His shorter entries, such as on Helena Rubinstein and Sir Kenneth Wheare, involved insight leavened by dry humour and sometimes firsthand knowledge of a subject. For instance, he used to tell the story that

the girl who assisted Miss Crouch at the Coleraine school was my stepgrandmother ... She said that Helena [Rubinstein] suggested that she go to Melbourne with her and start a beauty salon. My step-grandmother turned the offer down. She didn't think there was any money to be made in face cream.

From 1976 to 1987, Poynter was chairman of the $A D B$ 's publisher, Melbourne University Press. Since 1995 he has been a professorial fellow at the Australian Centre, University of Melbourne. He was awarded an ADB Medal in 2004.

Source: John Poynter, interviewed by Ann Turner (22-23 July 1999 and 28 February 2002), NLA. 
7. Working Parties: Recollections of the South Australian Working Party

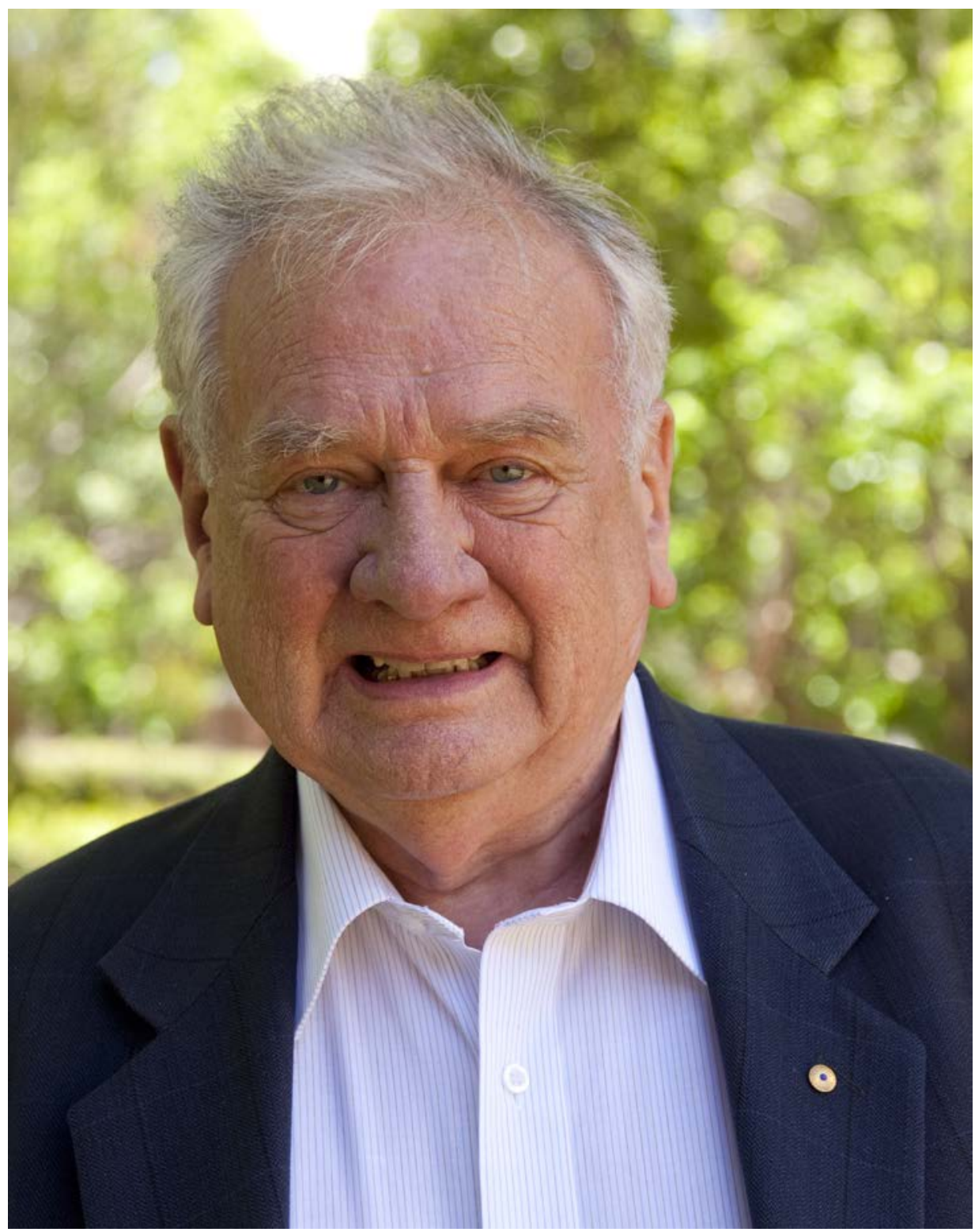

John Poynter, 2009

Photographer: Peter Fitzpatrick, $A D B$ archives 